\title{
The Formation of The Image of Conflict Situations By The Way of Mass Media
}

\author{
Demilkhanova Angelina, \\ $\mathrm{PhD}$, Associate professor, psychology department \\ Kyrgyz-Russian Slavic University, Bishkek, Kyrgyzstan, tel:+996556352517 \\ Denisova Oksana, \\ Senior lecturer, philosophy department \\ Kyrgyz-Russian Slavic University; Bishkek, Kyrgyzstan
}

\begin{abstract}
The article is devoted to the investigations of the formation of an image of the Syrian conflict in English and Russian electronic media (for example, electronic versions of such publications as: The Guardian, The Washington Post, The New York Times, Kommersant, Izvestia, Arguments and Facts).
\end{abstract}

Key words: conflict, Syrian conflict, mass media, discourse, manipulation of public consciousness, manipulation techniques.

\section{INTRODUCTION}

Nowadays the Syrian conflict is one of the progressive social conflicts. A series of social conflicts that have engulfed the whole of North Africa and parts of Asia, which began with Tunisia and Egypt in 2010, do not terminate until present. The conflict in Syria began with individual performances in January 2011, which in March took a widespread and organized character. This conflict continues to flare up till the present, despite numerous attempts to resolve it.

The purpose of our research was a comparative study of the materials on the events in Syria presented by English and Russian-language media since the start of the conflict. We have analysed the publications of the on-line versions of such press as: The Guardian, The Washington Post, The New York Times, Kommersant, Izvestia, Arguments and Facts. Time period - 1st point - the beginning of the event, in March 2011, the 2nd point - in December 2011, 3rd and 4th points with an interval of one year, ie December 2012 and 2013.

\section{MATERIAL AND METHODS}

The main research method was content analysis and discourse analysis. The basic hypothesis of our study was the assumption that different media have different methods of manipulating public opinion in order to create the desirable image of the particular social situation (which can be detected by the methods mentioned above).

It was chosen the headlines of specified newspapers for the analysis.

According to Teun Van Dijk, having the ability to control the production of discourses can influence the public opinion, to approve the desired ideology. T. Van Dijk highlighted the certain structures in the discourse, dividing them into local (grammar of sentence and grammar of text), the global structure (schematic superstructures and thematic macrostructures) and structures that permeate all levels (structuring by the principle of relevance and rhetorical structure). He also says that if we have a possibility to manage of 
discourse production, we can influence on a social conscience and approve the necessary ideology. And important feature of newspaper discourse is that topics may be expressed and signalled by headlines, which apparently act as summaries of the news text [1].

Describing the particular events and images, the mass media form definite perception, reflection and reaction of mass consciousness on these events. According to Marshal Mcluhan, in the modern era the mass media have functions of ideological and political influence, the organization and provision of information, education and entertainment and the function of maintaining social community [2].

\section{RESULTS AND DISCUSSION}

Media is not just covering certain series of incidents, but adds to it some emotional coloration. I. Zhukov wrote: "During the process of coverage of war events, the mass media are forming discourse versions of the reality and as a result we have the program that is directing the readership. The discursive versions of the reality are producing stereotypes and prejudices" [3].

The attitude of social groups to the military activities depends on how these events were presented by the mass media. And here we can even talk about the programming of thinking, because predefined opinion (the reality interpretation) in ideological pattern is given to the readership.

Moreover, for forming a certain impression the grammar constructions were used. Employing the active voice, some of them represent active hostilities, while others - the passive voice - the fact that the other party, such as an army, only responds to these actions. When working with verbs they emphasize grammatical category of voice in connection with the importance of the opposition of leader and victims and to identify the ideological orientation of the author / editors determines the object and subject of the action [3].

As a vivid examples in our samples might be presented the following: «Syrian reaction to Assad's speech» - Al Jazeera, «Chemical Arms Used Repeatedly in Syria» - New York Times, «A chemical weapons attack kills 1,400 in Syria», «US president reacts to reports that sensitive chemical weapons parts have been moved around the country by the Assad regime» - The Guardian.

The effect of argumentativeness is achieved by the citation.

In the military discourse of media often uses the references to senior sources, who did not want to call themselves (it is also the manipulation technique). As an illustration of this example we can see the following head-lines: New York Times: «Lebanon says army fired on Syrian helicopters»; Al Jazeera: «Syria Crisis Is Worsening, U.N. Relief Official Says», «ihadist Groups Gain in Turmoil Across Middle East», «Top U.N. Rights Official Links Assad to Crimes in Syria». It is said about the officials, that make the statements about undefined groups that are moving through the whole territory, but the specific names are not given.

The same techniques are widely used by the The Washington Post and The Guardian. The activists, officials and even simply resources are mentioned. The Washington Post: «Airstrikes by Syrian government kill at least 50 in rebel-held town near Aleppo, activists say», «Syrian conflict's sectarian, ethnic dimensions growing, U.N. warns», «Israeli officials say Assad is doomed». 
The Guardian: «NATO and WE officials say short-range missiles detected looked like Scuds, as Syrian opposition wins international recognition».

Analysing the impact of manipulative techniques on the public consciousness through the media Andrei Richter [4], among others, highlights such as:

- The naturalism of description of war realities (killed, wounded, body parts, etc.) causes an extremely negative attitude of society toward the described reality).

\section{Examples:}

Al Jazeera: «Attacks on Lebanon army posts leave five dead», «At least 125 people killed and scores injured by army air raids on rebel districts in Aleppo city», "At least 24 killed, mostly women and children, in two bomb attacks south west of Damascus ».

The New York Times: «Dozens Are Killed in Syrian Violence», «In Syria, Thousands Protest Killings». The Washington Post: «Airstrikes by Syrian government kill at least 50 in rebel-held town near Aleppo, activists say» (according to activists, The Syrian government Air Force killed at least 50 people in the rebel-held town ...).

The Guardian: «A chemical weapons attack kills 1400 in Syria», «Syrian crisis 'could kill 100000 in next year'», «and Syria blames al-Qaida after two car bombs kill dozens in Damascus».

Kommersant: «They kill even children». Izvestia: «In Syria, shot more than 70 military deserters», «From the bombings in Syria about 30 people were killing », "For three days in Syria killed more than 100 people ». Arguments and Facts: «Freelance reporter for Reuters was killed in Syria », «Syrian aircraft killed more than 60 people in the bread queue»

- The depersonalization of acting person (the lack of personal features) limits sympathy to described side.

Kommersant: «The Syrian opposition doesn't allow unite itself», «The opposition accuses the authorities of the use of chemical weapons». Izvestia: «Russia fears the victory of the Syrian opposition», "The Syrian opposition does not believe the retention of power of Assad». Arguments and Facts: «The opposition refused to go to Moscow for talks», "The Syrian army firstly has used the chemical weapons against the opposition»

Al Jazeera: «Syrian fighters join forces against al-Assad», «Syrian soldiers ' killed by army defectors'». The Guardian: «Syrian crisis 'could kill 100,000 in next year'».

The New York Times: «Russia Urges Assad to Negotiate with His Opponents», «Syria Fires More Scud Missiles at Rebels».

The Washington Post: «Islamic charity officials gave millions to al-Qaeda, U.S. says», «More than 100 dead in Aleppo airstrikes; United Nations warns of 'terrifying situation'».

In the given examples there is no personal information, the names or statuses of sources of information were not mentioned as well. Acts are impersonal forces - Syria, officials, UN, activists, the army that forms the impression of a huge "machine", to which it is very difficult to resist. At the same time the Washington Post widely presents the personalization of Obama. «Obama hails progress on loose nukes, warns of chemical weapons risk in Syria», «Obama warns Syria amid rising concern over chemical weapons». The personalization, conversely, 
leads to the formation of definite attitude to certain person, separates person from the mass, and leads to the perception of the person as having a power. In this case we can talk about the demonstration of specific intents of Barack Obama as legal and legitimate representative of certain country and a spokesman in the global stage.

It should be emphasized that in The Guardian the most part of statements is personalized. «Syria military police chief defects to rebels», «The Russian foreign minister says his country will not be an intermediary between Syrian president and those who want him to leave and seek safe haven abroad», «Russian deputy foreign minister's comments come as Syria rebels say 21-month conflict has reached turning point».

The personalization of the statements generates credence to certain resource, and creates an impression of objectiveness of coverage of events. In addition, such structures can be considered as an argument to authority- a reference to authoritative, significant personality that releases from the argumentation of certain standpoint, shifts the responsibility of given statements to the speaking person.

- Constant reference to the threat of the spread of the conflict beyond the region scares the mass consciousness by the threat of personal well-being, increasing the personal interest of every reader in the speedy resolution of the conflict. Localization of events within a particular region or a particular country produces unresponsiveness of mass consciousness to war.

Here are some examples: Kommersant: "The Syrian war becomes global." Al Jazeera: «Assad: Global plot against Arab nation». The New York Times: «To Save Syria, America Needs Russia's Help», «Syria's Chaos A Test for US».

The Washington Post: «Syrian conflict said to fuel sectarian tensions in Persian Gulf», «Syria's revolt a threat to neighbor».

The Guardian: «As there's no model of the war in Syria, it's impossible to forecast how the fallout will affect the region», «A year of uprisings and revolutions: uncertainty reigns in the Arab world».

Solidarization- it is an acceptance of any part of the conflict ("our", "they", "enemies"). Affection for described social group is forced to the audience.

The Washington Post: «The Obama administration is willing to support a Syrian rebel coalition that would include Islamist groups» The. New York Times: «Iran remains a destabilizing force in Syria, and its neighbors view its efforts to prop up President Basharal-Assad». Kommersant: "Commissary for Human Rights has accused the Syrian president of war crimes; Izvestia: "Syrian leader Assad denied the military repression"; Arguments and Facts: "Syrian aircraft killed more than 60 people standing in a bread queue".

\section{CONCLUSION}

Summing up the results of our study, we can note the following points:

In Al Jazeera the situations is mainly describing as negative (22\%), we can also see the description of the victims (18\%), at the same time as mentioning Bashar al- Assad and his supporting governmental forces are described in 2/3times less frequently. In general, more attention is given to the description of the situation in special war terms. 
The main parties of the conflict are described as negative in Kommersant (Bashar al- Assad (20\%) and opposition (16\%)). Significant attention is given to description of the 3rd side (44\%), that is specified as negative (16\%). Arguments and Facts and Izvestia give approximately equal attention to negative description of the situation (14\%) and mentioned Bashar al-Assad (23\%). The manipulative techniques, such as overstatement and metaphorization are used in headlines. "Syrian aircraft killed more than 60 people standing in a bread queue" (Arguments and Facts).

In general, the Russian language press has paid much less attention to the description of the Syrian conflict.

The Guardian, Assad is represented negatively (16.5\%), legitimate power at the moment (15.5\%), as well as the situation as a whole (17\%). The opposition presented objectively, description combine both positive and negative contexts. Also, considerable attention is paid to the description of a position of strength 3rd parties (20\%), at the same time emphasizes the opposition of the Russian Federation and the United States.

The Washington Post describes the situation as an extremely negative (18\%) are also sufficient attention is paid to the negative assessment of the actions of legitimate power (9.6\%). Assad was presented sufficiently objectively, providing both positive and negative sides. Clearly expressed support for the United States as a third party to the conflict and supported the opposition, and including associated with terrorist groups.

The New York Times describes Assad (23.6\%) in an extremely negative way, emphasizes its relationship with hackers and al-Qaeda, as well as emphasizes the negative situation as a whole $(15.5 \%)$. Considerable attention is paid to the description of the 3rd party, mostly in negative and threatening aspects (21.6\%).

In general, Russian-language media pay less attention to the description of the conflict situation in the CAP as a whole, but at the same time presented a negative "enemy image" (Assad and government forces, the army). The position of power of the Russian Federation is not pronounced. In the English-language media the number reports dedicated to this topic in 78 times more clearly expressed position of power of the 3rd party, considerable attention is given to describing the situation as negative.

\section{Bibliography}

Dijk, Teun Adrianus van, NEWS AS DISCOURSE. -LAWRENCE ERLBAUM ASSOCIATES, 1988. Hillsdale, New Jersey Hove and London.

Volodina L.V., Karpuhina O.K., 2002. Business communication and foundations of the theory of communication. Study guide. - St. Petersburg,

Zhukov I.V., 2002. A critical discourse analysis of printed media: light patterns of the North Caucasus conflict of 1998-2000.: Dissertation of the candidate of philological science.- Tver.

Richter A.G., 1998. Journalism and War (Russian media coverage of military operations in Chechnya) / Ed. By A.G. Richter. - //www.medialaw.ru/publications/books/war. Date of access 10/12/2013 